\title{
The Development of High-End Service Industry Based on Opening-Up of Services: A Case of Beijing
}

\author{
Haosen Xu, Liyan Liu* \\ School of Economics and Management, Beijing Institute of Petrochemical Technology, Beijing, China \\ Email: *lucyliuliyan@bipt.edu.cn
}

How to cite this paper: $\mathrm{Xu}$, H.S. and Liu, L.Y. (2019) The Development of High-End Service Industry Based on Opening-Up of Services: A Case of Beijing. Modern Economy, 10, 1897-1913. https://doi.org/10.4236/me.2019.108122

Received: June 24, 2019

Accepted: August 24, 2019

Published: August 27, 2019

Copyright (อ 2019 by author(s) and Scientific Research Publishing Inc. This work is licensed under the Creative Commons Attribution International License (CC BY 4.0).

http://creativecommons.org/licenses/by/4.0/

\begin{abstract}
As a pioneer city with the opening-up of China's service industry, Beijing has experienced a vigorous growth in its service sectors and served as a great example for the development of China's service industry since 2015. In early 2019, Beijing announced its full opening-up of service industry, becoming China's first open pilot city. In this study, we analyze the development of Beijing's service industry and find out the problems existing in the past four years. Under the background of overall opening, we also put forward some suggestions for the development of high-end service in this paper.
\end{abstract}

\section{Keywords}

High-End Service Industry, FDI (Foreign Direct Investment), Opening-Up of Service Sectors

\section{Introduction}

The global economic development has entered the era of "service economy". The economic development led by the high-end service industry has become the core content of the current service economy development. As one of the largest service economic countries in the world, the service industry has become the dominant economy in the United States, accounting for about $1 / 3$ of the global scale. Its characteristics are mainly reflected in the accelerated development of the high-end service industry in emerging fields and the accelerated agglomeration of high-end service resources in the core cities.

The opening of service industry and the development of service economy in core mega-cities have become an important engine of current economic development. Under the background of open economy, New York, London and ${ }^{\star}$ Corresponding author. 
Tokyo have formed an urban economic development model driven by the service economy led by the high-end service industry, and directly established the international status of their "international financial center", "world economic center" and "creative capital of the world". The international competitiveness and comprehensive economic strength of these mega-cities have also been continuously improved because of the development of their open service industry. The development of service economy based on the opening of service industry has become the core driving force of global mega-city economic development. Global services account for national production. The proportion of total value is growing rapidly, and the output and job creation ability of the service industry continue to rise. The open service industry has become the main force to promote the recovery and development of the global economy, and it is also a new driving force to stimulate the growth of foreign direct investment and international trade. With the in-depth development of the global value chain system, the essence of international direct investment and international trade has undergone fundamental changes, production is becoming more and more decentralized and fragmented, and the role of the service industry in the global value chain is becoming increasingly prominent. From the perspective of the global value chain, it is particularly important to promote the economic development of the service industry and the core mega-city through the opening of the service industry to the outside world, and then to give full play to the radiation effect of the service economy of the core mega-city.

Beijing, as the first service industry pilot in China, has already entered the era of service economy mainly driven by service industry. In terms of attracting foreign investment, the inflow of Beijing's service industry FDI increased from USD 345.67 million in 2006 to USD 23,201.85 million in 2017 and increased by $672 \%$ in 12 years. Foreign direct investment in service industry increased from $75.85 \%$ in 2006 to $95.37 \%$ in 2017. By 2017, the service industry almost absorbed all foreign direct investment in Beijing, the first industry only accounted for 0.03\%, and the second industry was $4.6 \%$. Almost all foreign direct investment in Beijing is concentrated in the service industry ${ }^{1}$. In terms of trade in services, by the end of 2017, Beijing's total import and export of services reached 143.426 billion US dollars, accounting for 44.3 percent of the total imports and exports. In terms of economic growth and job creation in the service industry, the tertiary industry in Beijing has led to more than $72 \%$ GDP growth in Beijing since 2001. By the end of 2017, the service industry economic growth had reached 86.6 percent, and job creation accounted for 80.6 percent of the city's jobs ${ }^{2}$. Beijing has developed into a service economy driven growth mega-city and based on the service industry opening to the outside world, the continuous development of high-end service industry is developing to the high-end service industry driven by the international super-core city. The development model of Beijing's open service economy has great reference significance and reference value for the develop${ }^{1}$ Data derived from and calculated according to Beijing Statistical Year Book (2018).

${ }^{2}$ Data derived from and calculated according to Beijing Statistical Year Book (2018). 
ment of other cities in the country. Under the background of the comprehensive opening of the service industry, the development problems and paths of the high-end service industry in Beijing can play a leading role in the development of the high-end service industry in other cities, and it has a strong practical significance.

\section{Literature Review}

Opening-up and the inflow of FDI have posed a significant impact on regional economic growth. Based on the provincial data of China, Sun Haishun [1] claimed that level of opening up, FDI, economic structure and policies have significant impact on economic growth. Yavarik [2] evaluated the impact of regional integration on boosting economic growth and bilateral FDI among the member countries of MENA, by using the Adjusted Gravity Model. And found that FDI can promote the rates of economic growth, and by utilizing their comparative advantages in different areas, the Islamic countries can ward off against the ill impacts of the globalization era. YiLu [3] evaluated the agglomeration effect versus the competition effect of FDI by distinguishing different types of FDI along various dimensions using an array of performance measures, including total factor productivity, exporting performance, wages, R \& D investment, and firm survival, and found that FDI has a positive impact on domestic firms. Based on the times series data and cross-sectional data from 1985-1999, Wei Houkai [4] found that FDI has a significant effect on regional economic growth, and of all the differences in the growth rates of GDP between coastal cities and western cities in China, almost $90 \%$ are contributed by FDI. Xiaohui Liu [5] investigates the causal links between trade, economic growth and inward foreign direct investment (FDI) in China at the aggregate level using quarterly data, and identified Long-run relationships between growth, exports, imports and FDI in a cointegration framework, and found that Economic development, exports and FDI appear to be mutually reinforcing under in opening-up context. Linda Fung-Yee Ng [6] used the firm level data consisting of 55,348 local Chinese and foreign manufacturing firms investing in Guangdong, China, and found that spatial agglomeration and their synergies as well as gravity have directed the patterns of inward FDI and further, induced regional GDP growth. While there are opposite options, such as Liyan Liu [7] endeavored to discern the long-run relationship between FDI and economic development in China under a more comprehensive framework, and found that FDI tends to decrease economic growth in the long run, and FDI inflows crowded out domestic capitals and reduce employment growth.

Opening-up and FDI inflow usually have positive effects on services development. Nadia Doytch \& Merih Uctum [8] tested with dynamic panel data and found that FDI in services would lead to the growth of services, and may impede the growth of manufacturing sectors. And Zhong Xiaojun [9] used cointegration and panel data model to analyze the causal relations between FDI in services and 
the growth of service industries in China, and results showed that there are long-term stable relations between FDI inflow in services and service growth. FDI in services presented a positive impact on the growth of various service sectors, which has its policy indications. Yao Zhanqi [10] investigated the opening-up in China's service industry, and found that FDI in services enhanced the upgrade of China's service industry in terms of global value chain through its technology spillover effects. Service trade and FDI in services brought about capital stock in $\mathrm{R} \& \mathrm{D}$, which raised the level of global value chain.

FDI in services can promote service growth through its technology spillover effects and job creation effects. Cheung Kui [11] found that FDI has strong positive effect on China's technology innovation, which is presented by the number of domestic patent applications, based on provincial data from 1995 to 2000. And the spillover effect is especially strong for minor innovation such as external design patent. While He Feng and Yuan Xiaoan [12] tested the spillover effect of FDI in services in China based on provincial data, and found that FDI in services has a strong inverted " $U$ " shape effect on technology rates of China. Liyan Liu [13] used EG co-integration method, Granger causality test and ECMs model tested the relationship between high levels of FDI and of employment and found that growth of FDI, in the long run, would promote employment level of service industry and hence promote growth of service sectors.

Current studies showed the relations between opening-up, FDI inflow and regional growth. The world economy has entered the era of "service economy" and opening-up has been a key driving factor in services development in opening economic context. As the supercity in China, Beijing is the first city to open its service sectors. How to upgrade Beijing's service industry, develop its high-end services based on further opening-up, has great significance for the rest of China.

\section{The Course of Opening-Up and the Development of High-End Service Industry in Beijing}

\subsection{The First Stage: From 2001 to 2014, the Initial Period of Beijing's Service Industry Opening to the Outside World ${ }^{3}$ and Develop the High-End Service Industry ${ }^{4}$ of Beijing}

Since China joined the World Trade Organization in 2001, the pace of service opening to the outside world has been accelerating, and the breadth and depth of opening up have been increasing year by year. In order to open the service industry to the outside world at various levels and in a wide range of fields, we must first broaden and utilize foreign capital channels, and secondly expand the

${ }^{3}$ The opening up on Beijing's service industry consists of domestic as well as foreign direct investment and services and import and export service trade.

${ }^{4}$ The high-end service industry refers to the high-tech, high value-added service industry and service modes at the top of the value chain, which is the jewel in the crown of modern service industry. The high-end service industry plays an important role in optimizing and upgrading the economic structure, accelerating the accumulation of endogenous factors to develop the economy, and promoting the quality of economic development. 
scope of foreign capital utilization. Finally, it is to improve the quality of the utilization of foreign capital. After China's accession to the WTO, China has changed its domestic obligations into international multilateral obligations, domestic responsibilities into international multilateral responsibilities, and the timetable for the reform and opening up of the domestic market into an international timetable. That is to open trade in services.

Since 2001, in accordance with the relevant commitments of China's accession to the WTO, Beijing has made looser regulations on the amount of capital, the scope of operation and the proportion of shares held in the field of foreign capital inflow. Therefore, in this stage, the opening area of Beijing to foreign capital has been further expanded, and most sectors, especially the service sector, have been opened in Beijing. During this period, the financial, information, business services, wholesale and retail, catering and accommodation industries developed rapidly. In 2007, the economic contribution rate of Beijing's service industry reached $74.9 \%$, far exceeding that of second industry (24.9\%), and the growth of gross domestic product (GDP) in Beijing reached 75.17 percent, far more than the 24.83 percent of second industry, and the average annual growth rate of service sector value added reached 12.9 percent, which was higher than the 0.8 percentage points of Beijing's annual gross domestic product during the same period. Beijing's high-end service industry has been initially developed during this period $^{5}$. In 2007, Beijing's financial industry, information transmission, software and information technology services, business services, scientific research and technology services and other high-end services accounted for more than $80 \%$ of the modern service industry in Beijing ${ }^{6}$.

From 2007 to 2014, with the entry into force of the catalogue of Foreign Investment Industry guidance, Beijing, including the service industry, basically, all the relevant open areas began to fulfill their commitments and gradually move towards globalization and opening-up in this catalogue of Foreign Investment Industry guidance. In 2014, the economic contribution rate of Beijing's service industry reached $78.3 \%$ far exceeding the second industry $(21.7 \%)$, and the growth of gross domestic product (GDP) in Beijing reached 7.95 percent, far more than the 2131 percent of second industry ${ }^{7}$. During this period, Beijing is committed to the development of the service economy, the headquarters economy and the construction of the world city, vigorously develop the service industry, and consciously guides and standardizes the inflow of foreign capital, which greatly increases the proportion of FDI in the service industry. At the same time, it is more inclined to attract investment in high-end, service-oriented, agglomeration, integration and low-carbonation, and guide foreign investment to serve in the north. The optimization of industrial structure and the upgrading of service industry in Beijing. The total amount of foreign capital utilized in Beijing's service industry continues to grow, and foreign direct investment has

${ }^{5}$ Data derived from and calculated according to Beijing Statistical Yearbook (2008).

${ }^{6}$ Data derived from and calculated according to Beijing Statistical Yearbook (2008).

${ }^{7}$ Data derived from and calculated according to Beijing Statistical Yearbook (2015). 
made certain contributions to the development of Beijing's service industry. The absolute quantity and proportion of FDI introduced into service industry in Beijing continue to rise, which realizes the steady and rapid growth of the absolute quantity and proportion of FDI foreign capital inflow in service industry at the same time.

\subsection{The Second Stage: From 2015 to 2018, the Opening-Up of Beijing's Service Industry to the Outside World Has Entered the Stage of Expanding and Opening-Up, and It Is Also the Rapid Development Stage of Beijing's High-End Service Industry}

In May 2015, the State Council approved the Comprehensive pilot Plan for the expansion and opening of Beijing's Service Industry. Beijing became the first city in China to carry out the comprehensive pilot project of expanding and opening up the service industry, and Beijing's service industry entered a new stage of opening to the outside world. During this period, Beijing further improved the investment layout, expanded the field of opening up, relaxed access restrictions, and actively and effectively introduced overseas funds and advanced technology. Orderly expansion of the service industry to the outside world, expand banking, insurance, securities, pension and other market access. At the same time, we should speed up the development of modern service industries and devote ourselves to building a "highly sophisticated" economic structure of the 2018 edition of "Foreign Investment access Special". The General Plan for deepening the Innovation and Development of Service Trade was approved, further relaxing the restrictions on the operation of foreign-funded enterprises in the service industry, further relaxing the deepening innovation in the field of service trade, and further strengthening the degree of opening up and internationalization to the outside world. Beijing's service industry gradually relaxes access restrictions, constantly improves the service industry development system, improves the development level of high-end service industry and service trade, further improves the regulatory system and regulatory model, optimizes the market environment, constantly optimizes the internal structure of the service industry, and strives forward in the direction of high-end, agglomeration and internationalization.

In terms of service industry output value, the added value in Beijing's service industry in 2017 was 2256.78 billion yuan, accounting for $80.6 \%$ of GDP. The added value of service industry increased by $0.4 \%$ over the previous year, and the contribution rate to economic growth was $86.7 \%$. The annual increase of 4.3 percentage points compared to the previous year. As a result, the service industry has become the main driving force for economic growth in Beijing, and it has also shown that the development of Beijing's service industry has matured.

In the aspect of utilization of foreign capital, on the one hand, the total amount of foreign capital utilized in Beijing's service industry has risen sharply. On the other hand, the structure distribution of foreign direct investment in Beijing's service industry has begun to turn. The foreign capital in the high-end ser- 
vice industry with high-tech content has gathered rapidly, and the foreign capital in the general service industry has been transferred out in large numbers. In terms of total amount, in 2017, in the third year of the pilot opening of Beijing's service industry, the actual utilization of foreign capital in the service industry reached 23.20185 billion US dollars, accounting for 95.4 percent of the total foreign capital utilization in Beijing in that year, 2.93 times as much as in 2014 before the pilot. During the three-year period of expanding the comprehensive pilot of opening up, Beijing has served the use of foreign capital by the industry has achieved an average annual growth rate of $43 \%$. By the end of 2018, more than 43,000 foreign-funded enterprises had been set up in Beijing by 165 countries and regions around the world, with a cumulative total of more than US $\$ 155$ billion in actual utilization of foreign capital. From the point of view of industry distribution, foreign capital gathered from the general service industry to the high-end service industry with high scientific and technological content, among which the information transmission, computer service and software industry in Beijing increased from 1.15292 billion US dollars to 13.17877 billion US dollars during the three years of pilot opening from 2014 to 2017, accounting for $5 \%$ of the actual foreign capital utilization in Beijing in 2017. 6.80\%. In 2014, the actual utilization of foreign capital in Beijing's leasing and business service industry was US $\$ 3.39759$ billion, accounting for $42.85 \%$ of the total foreign capital utilized in Beijing's service industry in that year. After the pilot opening up, there was a large outflow of foreign capital. In 2017, the actual utilization of foreign capital decreased to US $\$ 2.29595$ billion, and the proportion of service industry dropped sharply to $9.9 \%$. After the pilot opening up, the foreign investment in Beijing's service industry has rapidly gathered to the high-end service industry with high scientific and technological content, which has greatly changed the structure and pattern of the utilization of foreign capital in Beijing's service industry ${ }^{8}$.

In terms of service trade, during the three-year pilot period, Beijing's service trade has developed rapidly. In 2017, China's service import and export volume was 4.69911 trillion yuan, accounting for about 8 percent of the global service import and export volume. Beijing's imports and exports of service trade totaled US $\$ 143.43$ billion in 2017, accounting for 20.6 percent of the country's total. Among them, the proportion of exports of trade in services in imports and exports of services reached 30.5 percent, an increase of 10.6 percentage points over $2012^{9}$.

In the development of high-end service industry, the output value of high-end service industry with high-tech content in Beijing is growing at a high speed. The high-tech service industry has developed rapidly, and the achievements of scientific and technological innovation and cultural innovation have been remarkable. Science, technology and culture have become the core elements leading the upgrading of the service industry structure. In 2017, the added value of ${ }^{8}$ Data derived from and calculated according to Beijing Statistical Yearbook (2018).

${ }^{9}$ The data is derived from and calculated according to the Beijing Statistical Yearbook (2018). 
the high-tech service industry accounted for $19.3 \%$ of the regional gross domestic product. The added value of culture and related industries accounted for more than 9 percent of the region's gross domestic product. In 2017, 172,000 new service enterprises were added in Beijing, an average of 471 new registered enterprises per day, accounting for 94.5 percent of the total number of newly registered enterprises. Information in Transmission, software and information technology services, scientific research and technology services added 192 enterprises a day, accounting for 40.7 percent of the newly registered enterprises in the tertiary industry, up from 3.5 percentage points last year. In 2017, Beijing's information service industry, financial industry and science and technology services achieved an added value of 322.9 billion yuan, 465.54 billion yuan and 285.92 billion yuan, respectively ${ }^{10}$.

\subsection{The Third Stage: 2019-Beijing's Service Industry Has Entered the Stage of Comprehensive Opening to the Outside World, and at the Same Time, Beijing's High-End Service Industry has Entered the Stage of Deepening Its Development}

In February 2019, Reply of the State Council on promoting the Comprehensive pilot work Plan of Beijing's Service Industry was approved and issued. As a key industry for the comprehensive expansion of opening up, Beijing's rental and business services industry, information transmission, software and information technology services, finance, scientific research and technology services, health and social work, culture, sports and entertainment, Beijing will further open up to foreign investment from three aspects: service industry development, opening up to the outside world, and policy environment support. Beijing will open up a new pattern of attracting foreign investment in the service industry, promote development with opening up, change the mode of economic growth, and create a foreign capital flow of FDI in Beijing's service industry to enter a new stage of in-depth opening up. At the same time, with regard to the relevant national standards for the high-quality development of the service industry, the National Development and Reform Commission and other relevant departments are planning to formulate top-level design schemes such as the high-quality development strategy of the service industry, committed to the establishment of a standard system for the high-quality development of the service industry, and then encourage service enterprises to become bigger and stronger in terms of policy mechanism.

\section{Challenges in the Development of Beijing's High-End Services under the Framework of Further Opening-Up}

\subsection{High-Quality Foreign Investment and Business Policy Still Need to Be Improved}

As an important supplement to domestic capital, foreign direct investment (FDI) not only provides strong financial support for the development of Bei-

\footnotetext{
${ }^{10}$ The data is derived from the Beijing Statistical Yearbook (2018).
} 
jing's service industry, but also brings important spillover effects such as advanced management concept, management experience, talent training mode and so on. Foreign direct investment in service industry plays a very significant role in promoting the development of Beijing's high-end service industry. Therefore, it is still necessary to continue to give full play to market potential and "reform dividend", strengthen the policy guarantee for foreign direct investment, and enhance the continued attraction to foreign direct investment, especially highquality foreign capital with advanced technology and management experience. How to effectively guide foreign capital after the opening up of the service industry in an all-round way and in the fields of finance, health care, education, pension and so on, it is a challenge to attract high-quality foreign investment more effectively to serve the development of Beijing's high-end service industry and to improve the efficiency of high-quality foreign capital utilization.

In addition, in the process of utilizing foreign capital, Beijing, as a pilot city for comprehensive opening-up to the outside world, Beijing still has some problems in the environmental policy. If the external environment is not fully constructed, it is not specific. It is necessary to establish sound and perfect laws and regulations to correctly solve possible intellectual property issues and many more. Therefore, in the creation of the business environment, a series of policies should be formulated to improve the current high-quality foreign business policy system.

\subsection{The Import and Export Structure of Service Trade Needs Further Optimization}

In recent years, the volume of service trade in Beijing has shown an upward trend, and the trade in services has generally improved. In terms of trade volume, imports and exports totaled US $\$ 143.426$ billion in 2017, including US $\$ 43.721$ billion in exports, US $\$ 99.706$ billion in imports and US $\$ 55.985$ billion in trade deficit in services. From the point of view of the ownership of the service trade product industry, the surplus industry is other business services, with a surplus of $\$ 7.533$ billion in 2017; professional and management consulting services, with a surplus of US $\$ 5.733$ billion; and construction services, with a surplus of US $\$ 5.558$ billion; and the traditional service industry has a surplus of US $\$ 5.558$ billion. Beijing has a large surplus in the import and export of service trade $^{11}$.

Among the import and export structure of Beijing's service trade, tourism service industry ranks first in the deficit industry, with a deficit of US $\$ 41.864$ billion, including US $\$ 2.65$ billion in exports and US $\$ 99.706$ billion in imports, followed by transport services with exports of US $\$ 4.826$ billion, imports of US $\$ 26.822$ billion and deficit of US $\$ 21.996$ billion. Ranked third, fourth and fifth are technology, knowledge-intensive high-end service categories, the third high-tech content of intellectual property use deficit of US $\$ 3.748$ billion, of which exports are only US $\$ 313$ million, imports 4.062 billion. The fourth largest

\footnotetext{
${ }^{11}$ The data is derived from the Beijing Statistical Yearbook (2018).
} 
deficit in insurance services was US $\$ 3.996$ billion, including US $\$ 2.613$ billion in exports and US $\$ 6.609$ billion in imports, while the fifth largest deficit in R \& D transfer fees and commissioned R \& D was US $\$ 936$ million, US $\$ 88$ million in exports and US $\$ 1.025$ billion in imports. Among the service trade products with deficit, the deficit problem of high-end service products, especially science and technology, knowledge-intensive high-end service products, is obvious ${ }^{12}$.

Therefore, from the structure of service trade and deficit structure in Beijing, there is still great room for improvement of the high-end service industry with high-tech content in Beijing. The export structure of service trade is still at the middle and low end of the global value chain, the deficit structure is unreasonable, the high-tech content, knowledge-intensive high-end service trade products, especially intellectual property rights. Its related export structure still needs to be improved and improved, and the import and export structure of service trade still needs to be further optimized.

\subsection{Innovation Driving Factors Need to Be Further Strengthened}

The current development of high-end service industry in Beijing is mainly characterized by science and technology intensive, but in the high-end service products, the contribution of science and technology innovation factors is still in a low stage of development. High-end service industry is characterized by technology-intensive and knowledge-intensive. Innovation factor, as the main driving force of the development of high-end service industry, should contribute a great deal to the development of high-end service. The characteristics of knowledge-intensive and technology-intensive determine that the development of high-end service industry can improve the efficiency of factor allocation and reduce resource consumption and environmental damage. The information-intensive characteristics determine that the development of high-end service industry can promote the mixed development of information technology and industry at the same time. In order to realize the intensive growth of economy and the expansion of service radius, a new mode of production and organization with high labor productivity can be formed into the inefficient mode of production and organization. The talent-intensive characteristics determine the development of education, culture and other industries, can improve the quality structure of the labor force, meet the needs of a large number of talents caused by the high industrial structure, and provide sufficient intellectual support for the future high-quality economic growth of Beijing-Tianjin-Hebei region.

In the growth of information transmission, software and information technology service industry, scientific research and technology service industry in Beijing, innovation factors play a great role, but at present, the financial service industry, business service industry, education, culture, medical treatment, child care, architectural design, accounting audit, trade logistics, e-commerce and other service fields, whether in terms of innovative technology, innovative knowledge and innovative talents, are in a state of shortage. The intensity of

${ }^{12}$ The data is derived from the Beijing Statistical Yearbook (2018). 
knowledge and science and technology is still relatively low compared with the same sectors in developed countries, and the growth contribution of innovation drivers is not obvious, which needs to be further strengthened.

\subsection{The Development of High-End Services Supporting System Needs to Be Improved}

The physical foundation of the development of high-end service industry is a huge and convenient transportation network. On the one hand, the current traffic in Beijing mainly depends on buses, online car hailing, taxis, subway and other modes of transportation. Although Beijing has more than a dozen subway lines, due to the fact that the planning did not anticipate the current huge flow of people, the reserved development space is relatively small, and cannot provide oversized traffic to solve the subway passenger peak such as commuting and holiday peaks in a short period of time, and the subway coverage is more inclined to the urban area. It can only play a certain radiation effect on the suburbs, and it cannot meet the needs of tourists very well, which will reduce the service experience. On the other hand, modern services Commercial districts such as Xidan, Wangfujing, Sanlitun and so on are relatively concentrated, mainly located around the second Ring Road and important traffic sections in Changan Street area, which leads to the shortage of parking lots in each business district, and the traditional parking mode aggravates the traffic jam.

Any service deficiencies in the supporting system of high-end service industry will affect the quality of the whole high-end service industry, from the basic service industry supporting facilities, service infrastructure, service supplies, service consumer goods and so on. Without perfect supporting system, the traditional modern service industry management mode cannot attract customers for a long time. In order to provide a good space for the development of high-end service industry, Beijing should further improve the industry spatial layout of high-end service industry in order to provide a good space and industrial development ecosystem for the development of high-end service industry.

\section{The Development Path of Beijing's High-End Services Based on the Opening-Up of Service Sectors}

\subsection{Improve the Business Environment and Effectively Guide High Quality FDI}

Beijing should continue to open-up, improve the business environment, and provide a healthier development ecosystem for foreign investment entry and the development of high-end service industries. Balance the spatial layout of high-end service industry in Beijing, implement a new legal system of foreign investment, introduce tort punitive damages system, strengthen civil judicial protection and criminal protection, improve the level of intellectual property protection, so that the technology, production and other innovations of enterprises can be better and more widely protected. Further clarify the enterprise profit disposal mode and related provisions, improve the maneuverability of the policy. We will fully 
implement equal treatment and completely remove restrictions other than the negative list of foreign investment access to promote the high level of foreign investment in Beijing. The level of market access will treat all kinds of enterprises registered in Beijing equally, and establish and improve the complaint mechanism of foreign-funded enterprises. To relax the access threshold of the market, introduce international high-end services, multi-service supply, which has the restriction that foreign investment aircraft maintenance projects must be controlled by Chinese side, introduce the first foreign holding aircraft maintenance joint venture in China, and support qualified foreign capital institutions to apply for the establishment of bank card clearing institution according to law. In order to relax the access threshold in the cultural field, the restrictions on share ratio of foreign-invested performance brokerage institutions shall be canceled, and the establishment of foreign-owned performance institutions in specific areas is allowed. Strengthen investment protection and dispute friendly arbitration system. Through the dispute settlement mechanism, we should properly deal with the contradictions between domestic and foreign enterprises, enhance the trust of foreign-funded institutions in the Chinese market system, and promote the development of Beijing's high-end service industry.

While improving the business environment of foreign investment in Beijing, we should effectively guide high-quality foreign capital and improve the spillover effect of foreign capital in Beijing's high-end service industry. More convenience should be given to high-quality foreign capital with high scientific and technological content and knowledge-intensive foreign capital, especially to bring innovative science and technology and innovation management experience, which is conducive to the training of innovative talents. At the same time, such foreign investment should be encouraged to invest in Beijing's digital economy, finance, science and technology, cultural and creative, education, medical treatment and other high-end, emerging service and emerging service fields. At the same time, we should actively encourage all kinds of scientific research institutions, institutions of higher learning and high-tech foreign-funded enterprises in Beijing to establish strategic partnerships in the field of science and technology. At the same time, it also balances the competitive relationship between domestic and foreign investment, further enhances the spillover effect of foreign direct investment on Beijing's high-end service industry, and then promotes the innovative development of Beijing's high-end service industry.

\subsection{Reduce System Costs and Promote the Upgrading of Service Trade Structure}

To reduce the institutional costs of import and export of trade in services, further reduce tariff levels, strive to eliminate non-tariff barriers to trade, reduce institutional costs in import links, further improve the degree of trade facilitation, improve the efficiency of customs clearance supervision, promote freedom of international settlement, guarantee the freedom of cross-border movement of capital, explore a regulatory system for investment and trade that is in line with 
international rules, and implement more open management of the entry and exit of goods. At the same time, we should further promote economic and trade negotiations, improve dispute resolution mechanisms through free trade agreement negotiations, and enable more countries and regions to participate in the opening up of Beijing's service industry, so that Beijing's services and businesses can be made available. Products go out faster, increase their popularity in the international market, so that service trade export enterprises have a broader space for development, and then promote the two-way opening of Beijing's service industry at a higher level.

While reducing institutional costs, efforts should be made to improve the import and export structure of service trade, especially the service trade export structure. Among the service trade exports in Beijing, the proportion of traditional service projects is too large, and the export of high-tech and knowledge-intensive high-end service industries is low, especially intellectual property, financial insurance, research and development results services, and the proportion of exports is relatively low, mainly relying on imports. Service trade in core emerging service areas such as education, medical care, and pensions has a lower proportion of exports and a much larger space for improvement. From the perspective of global value chain, most of Beijing's service trade exports are at the low-end of the value chain. The imports of high-end service categories are far greater than those of exports, and the deficit is large. The surplus mainly comes from traditional service categories. Therefore, the upgrading of service trade involves not only the increase in the export value of service products, but also the upgrading of the structure of export service products. We should focus on the development of science and technology, knowledge-intensive high-end service industry, promote cooperation between domestic and foreign capital in the fields of science and technology, scientific research achievements, etc., enhance the competitiveness of Beijing's service trade export products, increase the added value of service products, and then promote the transformation and upgrade the structure of service trade in Beijing.

\subsection{Raise Technology-Intensiveness and Enhance the Creative Development of Services}

As a national center of scientific and technological innovation, Beijing is one of the core contents of the development of high-end service industry and high-end service economy by improving the scientific and technological intensity and knowledge intensity of the service industry and promoting the innovation and development of the service industry. Beijing has been increasing investment in science and technology in recent years, but the input-output ratio is still relatively low, especially in service R \& D. Service R \& D has characteristics that are not easy to measure and protect, such as new financial instruments, new sales concepts, new retail models and new service aggregates containing existing core products and services. At the same time, the technical content of service innovation model is not significant, which affects the intensity of service R \& D innova- 
tion. At the same time, Beijing is the first service economic city in China and the most developed region of the Internet economy. The industrial integration of service industry is developing rapidly, and the industrial integration is becoming more and more frequent.

Beijing should make use of the existing advantages of science and technology and the Internet to encourage the service industry to enhance the scientific and technological connotation of its service products and innovate and develop. On the one hand, from the service R \& D and R \& D results protection, formulate relevant intellectual property protection policies, encourage and protect the normal transformation of service R \& D and service R \& D results. We can encourage the application of new technologies and new models in the service industry, and give direct financial support to enterprises or public users who apply innovative business models, subsidize innovative services, innovate the insurance costs of innovative business model applications, and encourage insurance companies to develop new liability insurance products for innovative service applications. On the other hand, we should go into politics. In the formulation of policy, the preferential tax policy of high-tech enterprises shall be applied to the service innovation enterprises, and the relevant provisions for the identification of high-tech enterprises shall be extended to the service innovation (business model innovation) field, so that the enterprises with service innovation can enjoy the corresponding policies. In addition, the industrial integration in service product innovation should be further encouraged, and the service innovation involving application or integration of new technologies, change of industrial chain operation mode, industrial chain innovation coordination, related platform construction, as for the change of management mode, administrative supervision and market access, etc. shall be carried out in the aspects of market access, tax policy and public environment construction according to the characteristics of industrial integration. Policy support should be given. We can encourage the development of service innovation industries and emerging service fields that integrate science and technology industries, such as e-commerce, network culture and creative industries, mobile medical services, etc., and support market access, tax and other related policies.

\subsection{Strengthen Scientific Research Cooperation and a High-End Service Talent Team}

High-end service industry is a technology, knowledge-intensive industry. High-end service personnel is an important support for its development. Efforts should be made to build a team of high-end talents and support the development of high-end service industries. On one hand, we should enhance the cultivation of talents for high-end services by a variety of cooperation in the fields of science and technology. For example, the classified development plan of high-end service talents can be formulated to guide colleges and universities and social training institutions to develop different levels and types of high-end service professional education, and to train urgently needed talents in high-end service 
industry through different channels and forms. For example, we should support domestic colleges and universities, and vocational schools. They should strengthen the construction of relevant disciplines in the service industry and the construction of service personnel training bases and build strong ones. We can improve the government purchase training mechanism, encourage vocational colleges, training institutions to provide inclusive service industry vocational skills training. We also can guide colleges and enterprises to carry out in-depth cooperation, innovation of applied, compound service personnel training model. We will actively and steadily promote the opening of education to the outside world, introduce foreign high-quality educational resources, and cultivate high-level Sino-foreign cooperative school-running projects.

On the other hand, there are many ways to introduce high-end service talents at home and abroad. Such as relaxing the restrictions on the household registration of high-end service talents, creating an environment for high-end talents to live and work in peace and contentment, developing specialized and international social talent intermediary organizations, widening the channels for attracting talents, and so on. At the same time, we should persist in attracting talents and attracting investment, explore the international mutual recognition of professional qualifications, and promote the flow of professionals and professional services at home and abroad.

\section{Conclusions}

Since the opening-up of Beijing's service industry in 2015, Beijing's service-driven economic growth mode has been further developed during this four-year period. By the end of year 2018, about 640200 service companies have been established, among which foreign invested service companies accounted for 95.2 percent; contribution of services in Beijing's economic growth increased to $87.9 \%$; service trade volume exceeded 1 trillion-yuan, accounting for $20 \%$ of the total national service trade volume. And during this period, high-end services have been the core of service development ${ }^{13}$. In the beginning of year 2019, Beijing announced its full opening-up of Beijing service sectors. FDI in service sectors and the high-end services development will enter a new era.

In this paper, we reviewed the stages of Beijing's opening-up of service sectors and the development of high-end services, analyzed the changes Beijing currently confronted with in the development of Beijing's high-end services under the framework of further opening-up, including the improvement of high-quality foreign investment and business policy, the optimization of the import and export structure of service trade, the improvement of innovation driving factors, and the further development of high-end services supporting system; based on the foregoing study, we proposed suggestions on the development Beijing's high-end services based on the opening-up of service sectors, from the aspects of business environment and FDI introduction sectors, system costs and upgrading of service trade structure, technology level and creative development of services,

\footnotetext{
${ }^{13}$ The data is derived from the Beijing Statistical Bulletin (2019).
} 
and high-end service talents cultivation.

\section{Supporting Projects}

1) The Coupling Mechanism between FDI and Employment Structure in Beijing, Beijing Municipal Education Commission Project (SM201510017001). 2) The Optimization of Beijing's Industrial Structure Based on SFDI, Beijing Social Science Foundation Project (13JGC072). 3) The Optimization of Beijing's Industrial Structure Based on FDI in Services, Beijing URT Project (2019J00140). 4) Support Project of High-level Teachers in Beijing Municipal Universities in the Period of 13th Five-year Plan.

\section{Conflicts of Interest}

The authors declare no conflicts of interest regarding the publication of this paper.

\section{References}

[1] Sun, H. and Parikh, A. (2001) Exports, Inward Foreign Direct Investment (FDI) and Regional Economic Growth in China. Regional Studies, 35, 187-196.

https://doi.org/10.1080/00343400120039597

[2] Yavari, K., Najarzadeh, R. and Shaghaghi, S.V. (2005) Regional Convergence and Its Impact on Foreign Direct Investment (FDI) and Economic Growth. The Economic Research, 5, 67-89.

[3] Lu, Y., Tao, Z. and Zhu, L. (2017) Identifying FDI Spillovers. Journal of International Economics, 107, 75-90. https://doi.org/10.1016/j.jinteco.2017.01.006

[4] Wei, H. (2002) Impact of FDI on China's Regional Economic Growth. Economic Research Journal, 4, 19-26+92-93.

[5] Liu, X., Burridge, P. and Sinclair, P.J.N. (2002) Relationships between Economic Growth, Foreign Direct Investment and Trade: Evidence from China. Applied Economics, 34, 1433-1440. https://doi.org/10.1080/00036840110100835

[6] Fung-Yee Ng, L. and Tuan, C. (2006) Spatial Agglomeration, FDI, and Regional Growth in China: Locality of Local and Foreign Manufacturing Investments. Journal of Asian Economics, 17, 691-713. https://doi.org/10.1016/j.asieco.2006.06.008

[7] Liu, L. (2011) FDI and Economic Development: Evidence from Mainland China. Journal of Service Science and Management, 4, 419-427. https://doi.org/10.4236/jssm.2011.44047

[8] Doytch, N. and Uctum, M. (2011) Does the Worldwide Shift of FDI from Manufacturing to Services Accelerate Economic Growth? A GMM Estimation Study. Journal of International Money and Finance, 30, 410-427. https://doi.org/10.1016/j.jimonfin.2011.01.001

[9] Zhong, X. (2009) Growth Effect of FDI in Services on Services Sectors in China. Technology Economics and Management, 4, 92-95.

[10] Yao, Z. (2018) China's Raising on Global Value Chain from the Viewpoint of Opening-up of Services. Academic Forum, 4, 92-101.

[11] Cheung, K. and Ping, L. (2004) Spillover Effects of FDI on Innovation in China: Evidence from the Provincial Data. China Economic Review, 15, 25-44. https://doi.org/10.1016/S1043-951X(03)00027-0 
[12] He, F. and Yuan, X. (2010) The Spillover Effect of SFDI in China and the Empirical Test-SFA Analysis Based on Provincial Data. The Journal of Quantitative \& Technical Economics, 6, 99-103.

[13] Liu, L. (2012) FDI and Employment by Industry: A Co-Integration Study. Modern Economy, 3, 16-22. https://doi.org/10.4236/me.2012.31003 